\title{
ARTICLE \\ GIS Based Approach to Determine the Changes of Water Hyacinth (Eichhornia crassipes) Cover and Relation with Lesser Whistling Teal (Dendrocygna javanica) Assemblage at Santragachi Wetland, West Bengal
}

\author{
Masuma Begam $^{1}$ Sudin Pal ${ }^{2 *}$ Niranjita Mitra $^{3}$ Asitava Chatterjee ${ }^{4}$ Anirban Mukhopadhyay $^{5}$ \\ Subhra Kumar Mukhopadhyay ${ }^{2}$ \\ 1.Directorate of Forest, Working Plan \& GIS Circle, Aranya Bhavan, Salt Lake, Kolkata- 700098, India \\ 2.Ecotoxicology and Environmental Technology Project Laboratory, Government College of Engineering and Leather \\ Technology, Salt Lake, Kolkata-700098, India \\ 3.Office of The Divisional Forest Officer, North 24 Parganas Division, Barasat -700124, India \\ 4.Office of The Divisional Manager, Purulia Forest Development Corporation Limited, Purulia- 723101, India \\ 5.Manitoba University, Winnipeg, Manitoba- R3T 2N2, Canada
}

\section{ARTICLE INFO}

Article history

Received: 22 February 2021

Accepted: 12 March 2021

Published Online: 30 March 2021

\section{Keywords:}

Lesser whistling teal

Water hyacinth

Correlation matrix

Cluster analysis

Santragachi wetland

\begin{abstract}
The present investigation is conducted to study the year wise (2011 to 2018) changes of water hyacinth (Eichhornia crassipes) cover at Santragachi Lake a Wetland under National Wetland Conservation Programme of India. Further the relationship between water hyacinth cover and the most abundant migratory waterbirds of Satragachi, Lesser Whistling Teal (LWT; Dendrocygna javanica) is assessed because this bird species is prefer depending on water hyacinth mat for their roosting. The study comprises of eight satellite images procured from Google earth (2011 to 2018) to explore this relationship. A marked decline in the number of LWT at Santragachi wetland is observed in the year of 2017 and 2018. It is very interesting fact that from 2017-2018, the water hyacinth mat of this wetland is almost cleared before winter and the result of cluster analysis supports this fact. Significant positive correlation is also observed within LWT number and water hyacinth cover area $(r=0.7481$ at $\mathrm{p}<0.05)$ along with the total perimeter $(r=0.8648$ at $p<0.05)$ of the water hyacinth islands at Santragachi wetland. However, open water area is also needed for diving, swimming, food searching for the LWT and other waterbirds. Therefore, more study is needed to optimize the clearing operations, focused on optimizing the shape and size of water hyacinth islands for proper management of the waterbirds habitat.
\end{abstract}

*Corresponding Author:

Sudin Pal,

Ecotoxicology and Environmental Technology Project Laboratory, Government College of Engineering and Leather Technology, Salt Lake, Kolkata-700098, India;

E-mail: sudindgp1@gmail.com 


\section{Introduction}

Increase in human population generates a huge amount of domestic and industrial wastewater, which discharge into the lake or river system, helping the invasive species to spread resulting in eutrophication and a steady decline of freshwater ecosystem. Furthermore, anthropogenic activities and extreme weather events may accelerate invasive species propagation. Taking into the account of invasive species, water hyacinth is rated as one of the hundred most harmful invasive species by IUCN ${ }^{[1]}$. The water hyacinth (Eichhornia crassipes) is fast growing, free-floating, stoloniferous, freshwater perennial plant indigenous to South America ${ }^{[2]}$. This plant which is introduced as an ornamental species more than a decade, has spread at least fifty country, including India and created serious socioeconomic and environmental problems to the people associated with aquatic ecosystem. It has estimated that under favorable environmental conditions, especially land surface temperature and nutrient content of aquatic ecosystem, 10 water hyacinth plants can reproduce 655,360 plants within 8 months and can cover almost 0.5 ha of the surface water ${ }^{[3]}$. Due to this reason water hyacinth also recognized as one of the top 10 worst

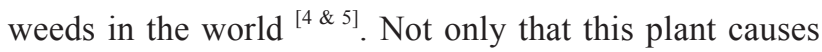
ecological alteration and consequently disrupts the nutrient cycle, food web structure, and invertebrate-fish assemblage in aquatic ecosystem ${ }^{[6]}$. Different studies have shown that the relationship of water hyacinth cover and zooplankton population is inversely proportional ${ }^{[4 \& 7]}$. Water hyacinth form of a blanket like layer over aquatic ecosystem, which prevents sunlight into the hypolimnion part of the water body, reducing photosynthesis rate for the submerged aquatic plants ${ }^{[8]}$. This condition disrupts aquatic species diversity and create non-conducive, unproductive ecological conditions ${ }^{[9 \& 10]}$. This inhabitable unproductive condition results hypoxia and create favorable condition different pests and diseases viz. filariasis, malaria, schistosomiasis, ancephalitis, and other water born disease ${ }^{[11 \& 12]}$. Moreover, the rate of evapo-transpiration of water hyacinth is 2-8 times more than the evaporation from free water surface, resulting hydrological alteration due to heavy water loss from water body ${ }^{[13 \& 14]}$. Furthermore, high rate of organic-matter production by water hyacinth accelerate the decomposition rate, results more $\mathrm{CO}_{2}$ and $\mathrm{CH}_{4}$ generation from water body ${ }^{[15 \& 16]}$.

However, besides various drawbacks of water hyacinth, it helps in pollution mitigation and acts as a bio-indicators of pollution. Water hyacinth efficiently remove mineral, especially different heavy metals from the aquatic system and serving as biological sinks. Different research works has been done on the water hyacinth and these studies have shown that this plant not only remove the minerals but also reduces amounts of total suspended solids, dissolved solids dissolve organic carbon, redox potential, turbidity, salinity, coliform bacteria, different organic pollutants like dyes, phenols, aldehyde etc. and numerous inorganic chemicals from domestic and industrial wastewater. Moreover, properly managed water hyacinth cover plays a significant role for plankton, microinvertebrates and fish by providing shelter, habitat, feeding grounds and breeding grounds ${ }^{[9,17 \& 18]}$. Therefore, monitoring and management of water hyacinth cover is necessary at present time to control pollution or to mitigate pollution in freshwater ecosystem.

On the other hand, nowadays, advance technology like GIS, remote sensing is widely used in different applications viz. land use - land cover change, vegetation and forest cover change, disaster monitoring and hydrology changes ${ }^{[19-25]}$. The assessment of present and future scenario of water resources, river dynamics, wetland biogeography, climate change, agriculture productivity, flood mapping are very crucial for better understanding about spatial distribution of surface water ${ }^{[16 \& 27]}$. For the extraction of surface water character and surface water cover, various image processing techniques have been applied in recent times. Moreover, to understand the spatial and temporal distribution of aquatic macrophytes GIS based study is a timely and cost-effective approach ${ }^{[28 \& 29]}$. Penatti et al. ${ }^{[30]}$ has stated that constant coverage of satellite sensors deals spatial data for environmental monitoring, which is essential in detecting and evaluating the strengths of the control procedures in place. Also, the use of satellite imagery has verified to be a dependable primary data, which become frequently applied in ecological and environmental research ${ }^{[25]}$.

In the last couple of decades, despite a marked decline in the number of migratory waterbirds on the West Bengal wetlands, Santragachi jheel (Wetland under National Wetland Conservation Programme) near a crowded and noisy railway station, regularly supports 4000-5000 migratory waterbirds. Especially, the bird's density in Santragachi Jhill was decreased significantly in 2017-2018 than past and from 2017-2018, the water hyacinth mat of Santragachi Jhill were fully cleared before winter due to the National Green Tribunal Verdict, 2016. In the present study an attempt has been made to use satellite images to map the area of Santragachi Jhill covered by water hyacinth 
during last 8 years (2011-2018) and to find out the effect of water hyacinth cover, if any, on the most abundant Lesser Whistling Teal (Dendrocygna javanica) colonization at Santragachi Jhill.

\section{Materials and Methods}

\subsection{Study Area}

Santragachi Lake is $8 \mathrm{~km}$ from the center of Calcutta City, in Howrah District, West Bengal, India (2234'60”N, $88^{\circ} 17^{\prime} 60^{\prime \prime} \mathrm{E}$; at an elevation of $8 \mathrm{~m}$ ). The area of this wetland is 12.8 -ha.

\subsection{Estimation of Density of Lesser Whistling Teal (LWT; Dendrocygna Javanica)}

The study of LWT was conducted in Santragachi jheel, during the winter months of December-February for 8 consecutive years (2011-2018). A group of three trained observers recorded wintering waterbirds blind-folded over three specific time intervals (06:00-07:00, 12:00-13:00 and 17:00-18:00 hrs) of a day and averaged to obtain representative data ${ }^{[31]}$ (Gibbons and Gregory, 2006). During each sampling time we traversed all the sides of the wetland where it was approachable. We surveyed each side by walking along a transect length of $1 \mathrm{~km}$ and counted all LWT seen within $50 \mathrm{~m}$ of transect using TruePlus 360 Laser range finder. All the LWT observed more than 50 $m$ on both sides of the transect line were recorded as long as they were within $50 \mathrm{~m}$ perpendicular to transect. LWT which were flying or perching were also recorded separately along with those using the habitat directly. We also conducted random binocular-field counts of the populations of LWT to obtain a more-robust area-wise estimate ${ }^{[32-35]}$. A Nikon Fieldscope (25-75 x 82 ED), Bushnell Equinox Z (4.5 X 40) Night Vision and Nikon Action (10 $X$ 50) binoculars were used for spotting the character details of the birds in sight.

\subsection{Preparation of Water Hyacinth Cover Maps}

The images of Google Earth were used to execute the study. Software used in the change detection of this study ERDAS imagine were used for referencing Arc GIS 9.1 software were used for digitization in the water hyacinth change detection study.

\section{Result and Discussion}

The result of this study delineates the areal changes of Santragachi Lake during 2011 to 2018 (Figure 1 and
Figure 2). In the year 2011, Santragachi wetland comprises 12.89 ha area. The study has found that the water hyacinth patch was 4.59 ha $(36.15 \%$ of total area) and the open water area was 8.23 ha (63.84\% of total area) in the year 2011. The total area, which comprises Santragachi Lake from the year 2012 to 2018 were 13.49 ha, 13.61 ha, 13.61 ha, 12.58 ha, 12.7 ha, 13.2 ha and 13.49 ha respectively. In the year 2012, the lake subsumes 3.77 ha area as open water (27.94\% of total area) and 10.31 ha area as the patch of hyacinth $(72.05 \%$ of total area). The open water in the year 2013 was 3.54 ha (26\% of total area) and the patch of hyacinth covers 10.07 ha ( $73.9 \%$ of total area). In the year 2014, the area of open water was 4.08 ha (30\% of total area) and the area of hyacinth was 9.53 ha (70\% of total area). The area of open water, from the year 2015 to 2018 were 8.5 ha ( $67.56 \%$ of total area), 11.37 ha $(89.52 \%$ of total area), 13.06 ha (98.9\% of total area) and 13.23 ha (98\% of total area) respectively. The area of hyacinth patches were 4 ha (31.7\% of total area), 1.33 ha $(10.47 \%$ of total area), 0.14 ha (1.06\% of total area) and 0.26 ha (1.06\% of total area) from 2015 to 2018 respectively (Figure $1 \&$ Figure 2).

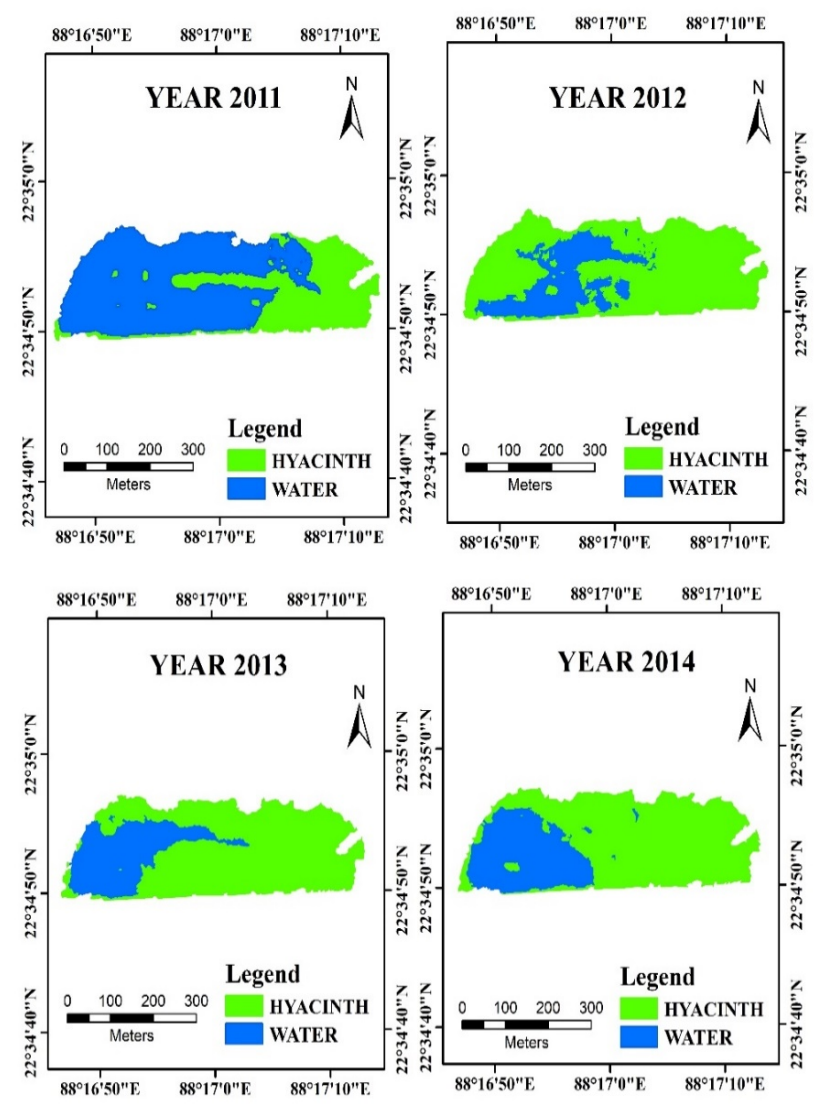

Figure 1. GIS based change detection of water hyacinth cover at Santragachi wetland during 2011-2014. 


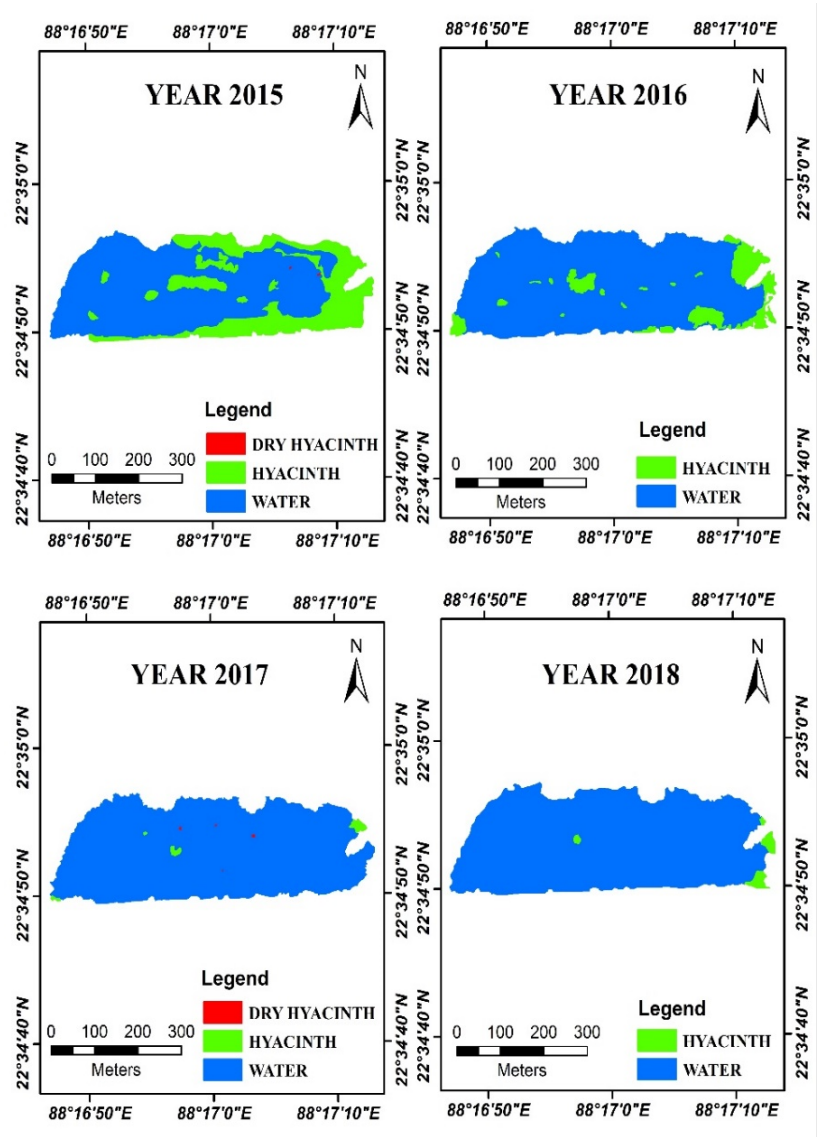

Figure 2. GIS based change detection of water hyacinth cover at Santragachi wetland during 2015-2018.

On the other hand the number of LWT was estimated 5232 - 7074 from 2011 to 2016. But after that a sharp decrease of LWT number was observed in 2017 and 2018. In 2017 the number of LWT was 2920 and in 2018 it was 707 only. It was depicted from Figure 3 and Figure 4 that the total perimeter of water hyacinth islands/ patches and water hyacinth cover in 2017-2018 was also decreased. From the cluster analysis it has been shown that 2017 and 2018 were distantly cluster with rest of the six years (Figure 5). Actually the water hyacinth mat of Santragachi Jhill were almost cleared in 2017-2018 before winter due to the National Green Tribunal Verdict, 2016. Thus the decline of LWT number in 2017-2018 was may be due to the decrease of water hyacinth cover area (WHCA) and perimeter. Actually, floating water hyacinth mat surely provided habitat and cover for aquatic invertebrates and fish that ensured a prey base for many bird species. It is the additional foraging habitat for large wading birds, such as the Egrets, Herons and Coots. Great diversity of aquatic macro- and micro-invertebrates are found along the edges of water hyacinth mats and fish could benefit from highly fragmented mats of water hyacinth. Point to be noted that in the present study our concern LWT fully depends on water hyacinth mat for their roosting. The significant positive correlation $(r=0.7481$ at $p<0.05)$ between LWT and WHCA also corroborates with this water hyacinth dependent roosting behavior of LWT (Table 1). Furthermore, the number of patches and total perimeter were also important because LWT mostly used periphery of the water hyacinth cover for roosting. Significant positive correlation $(r=0.8648$ at $p<0.05)$ also found between LWT and total perimeter of water hyacinth islands. In contrast, dense water hyacinth blanket over a large surface area would physically prevent waterbird to access to prey and, thereby, negatively impacted waterbird density with the increasing water hyacinth cover. The concern LWT is a diving duck and collect food from the deep water. So, area of open water is also very important for LWT. Therefore, more study is needed to find out the optimum water hyacinth cover area, open water area and number of islands for proper management of the LWT and other wintering waterbirds habitat.

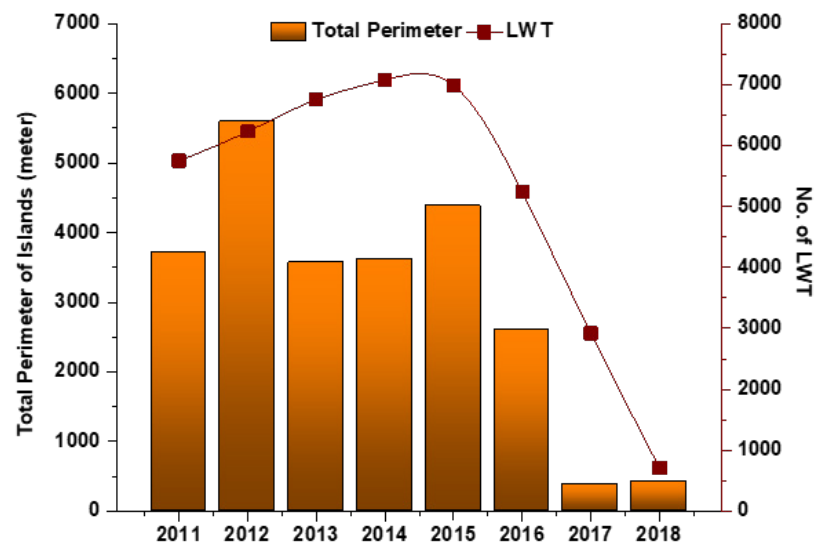

Figure 3. Changes of Lesser Whistling Teal (LWT) number in accordance with the total perimeter at Santragachi Wetland

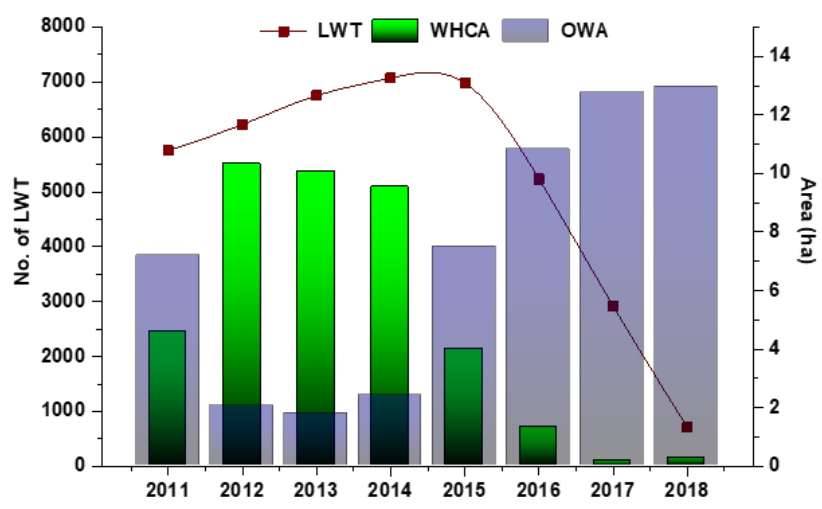

Figure 4. Changes of Lesser Whistling Teal (LWT) number in accordance with water hyacinth cover area (WHCA) and open water area (OWA) at Santragachi Wetland 


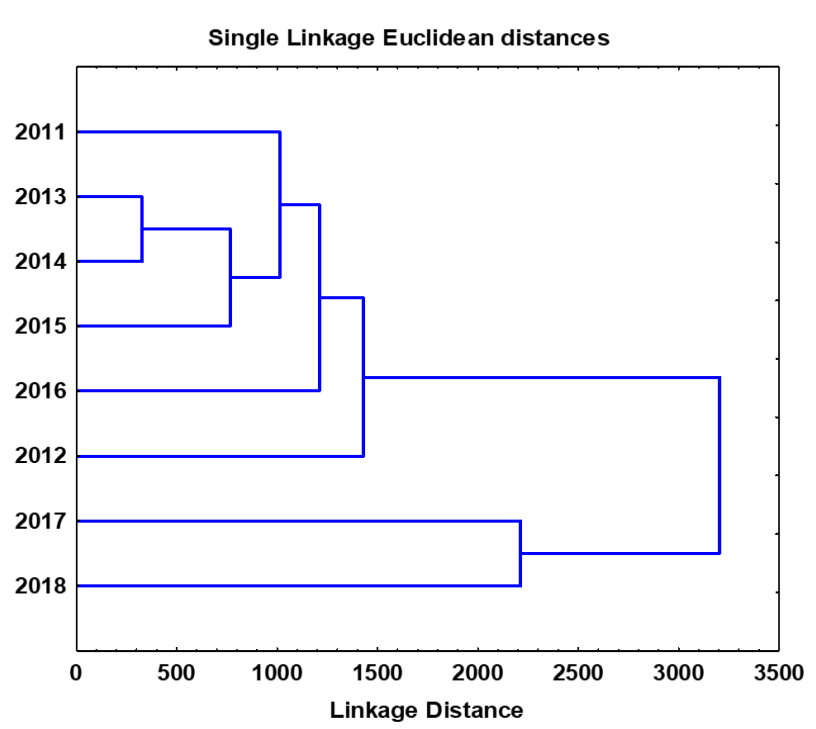

Figure 5. Hierarchical cluster analysis (single linkage Euclidean distances) of eight years depending on Lesser Whistling Teal number, open water area, water hyacinth cover area and total perimeter of islands

Table 1. Correlations within Lesser Whistling Teal (LWT) number and open water area (OWA), water hyacinth cover area (WHCA), and total perimeter of islands (TP) of Santragachi wetland (Bold red color face correlations are significant at $\mathrm{p}<0.05)$.

\begin{tabular}{|c|c|c|c|}
\cline { 2 - 3 } \multicolumn{1}{c|}{} & LWT & \multicolumn{1}{c}{} \\
\hline OWA & -0.8099 & OWA & \multicolumn{1}{c}{ WHCA } \\
\hline WHCA & 0.7481 & -0.9943 & 0.7838 \\
\hline TP & 0.8648 & -0.8226 & \\
\hline
\end{tabular}

\section{Conclusions}

Major findings of this work are that scientific weed management is one of the most important prerequisites for increased richness and abundance of migratory waterfowls. There are numerous wetlands of varying sizes in West Bengal, from north to south. Most of these land bound wetlands in the river plains attract varieties of migratory birds those depend on lentic freshwater bodies for feeding and resting, especially during the winter season. Usually many of these wetlands are weed chocked in the natural retrogressive fate of lentic situations. Optimal clearing of weeds, especially the floating weeds, well ahead of the wintering season for migratory waterfowl congregation, would be most important conservation criterion to attract these creatures to their feeding grounds because foraging guild structure and niche characteristics of waterbirds depends on it ${ }^{[36 \& 37]}$. This work has worked out the basic premise to optimize the clearing operations, focused on optimizing the shape and size of the islands of floating weeds and pointed out the importance of vegetation as direct or indirect food sources.

\section{References}

[1] Téllez, T., Lopez, E., Granado, G., Pérez, E., Lopez, R. and Guzmon, J. (2008), "The water hyacinth, Eichhornia crassipes: an invasive plant in the Guadiana River Basin (Spain)", Aquat. Invas., 3, 42-53.

[2] Gopal, B. (1987), "Water hyacinth”, Elsevier Science Publishers, Amsterdam, p. 471.

[3] Gunnarsson, C.C. and Petersen, C.M. (2007), "Water hyacinths as a resource in agriculture and energy production: A literature review", Waste Management, 27, 117-129.

[4] Mironga, J.M., Mathooko, J.M. and Onywere, S.M. (2014), "Effects of spreading patterns of water hyacinth (Eichhornia crassipes) on zooplankton population in Lake Naivasha, Kenya". Int. J. Develop. Sustain., 3(10), 1971-1987.

[5] Patel, S. (2012), "Threats, management and envisaged utilizations of aquatic weed Eichhornia crassipes: an overview”. Rev. Environ. Sci. Biotech., 11, 249-259.

[6] Coetzee, J.A., Jones, R.W. and Hill, M.P. (2014) "Water hyacinth, Eichhornia crassipes (Mart.) Solms-Laub. (Pontederiaceae), reduces benthic macroinvertebrate diversity in a protected subtropical lake in South Africa", Biodivers. Conserv., 23, 1319-1330.

[7] Chukwuka, K.S. and Uka, U.N. (2007), "Effects of water hyacinth (Eichhornia crassipes) infestation on zooplankton population in Awa Reservoir, Ibadan South-west Nigeria”, J. Biol. Sci., 7(6), 865-869.

[8] Huang, X.Y., Lan, J.L., Su, M.X., Shi, H., Lin, K.M. and Zhu, Y.Q. (2007), "Polymorphism of biological characteristics of Eichhornia crassipes". China Agri. Sci. Bull., 23(8), 98-101.

[9] Villamagna, A.M. and Murphy, B.R. (2010), "Ecological and socio-economic impacts of invasive water hyacinth (Eichhornia crassipes): a review", Freshwater Biol., 55, 282-298.

[10] Stiers, I., Crohain, N., Josens, G. and Triest, L. (2011), "Impact of three aquatic invasive species on native plants and macroinvertebrates in temperate ponds", Invas. Biol. Invas., 13, 2715-2726.

[11] Reddy, K.R. and DeBusk, W.F. (1991), "Decomposition of water hyacinth detritus in eutrophic lake water", Hydrobiol., 211, 101-109.

[12] Thamaga, K.H. and Dube, T. (2018), "Remote sensing of invasive water hyacinth (Eichhornia crassipes): 
A review on applications and challenges", Remote Sens. Appl.: Soc. and Environ., DOI: 10.1016/j.rsase.2018.02.005

[13] Holm, L. G., Plucknett, D. L., Pancho, J. V. and Herberger, J. P. (1977), "The World's Worst Weeds", Distribution and Biology, Honolulu, p. 606.

[14] Hill, M. P. (1998), "In Proceedings of the First IOBC Global Working Group Meeting for the Biological and Integrated Control of Water Hyacinth", Zimbabwe, p. 182.

[15] Pal, S., Aich, A., Chattopadhyay, B. and Mukhopadhyay, S.K. (2016), "Carbon sequestration and its relation with some soil properties of East Kolkata Wetlands (A Ramsar Site): A spatio-temporal study using radial basis functions", J. Model. Earth Syst. Environ., DOI 10.1007/s40808-016-0136-4.

[16] Pal, S., Chattopadhya, B., Datta, S. and Mukhopadhyay, S.K. (2017), "Potential of Wetland Macrophytes to Sequester Carbon and Assessment of Seasonal Carbon Input into the East Kolkata Wetland Ecosystem", Wetlands, 37(3), 497-512.

[17] Brendonck, L., Maes, J., Rommens, W., Dekeza, N., Nhiwatiwa, T., Barson, M., Callebaut V., Phiri C., Moreau, K., Gratwicke, B., Stevens, M., Alyn N., Holsters, E., Ollevier, F. and Marshall, B. (2003), "The impact of water hyacinth (Eichhornia crassipes) in a eutrophic subtropical impoundment (Lake Chivero, Zimbabwe). II. Species diversity", Archiv Fur Hydrobiol., 158, 389-405.

[18] Chatterjee A., Adhikari S., Pal S. and Mukhopadhyay S.K. (2020), "Community structure of migratory waterbirds in two important wintering sites at sub-Himalayan forest tract in West Bengal, India”, The Ring, 42, 15-37.

[19] Rindfuss, R.R., Walsh, S.J., Turner, B., Fox, J. and Mishra V. (2004), "Developing a science of land change: challenges and methodological issues", Proceed. Nat. Acad. Sci. 101, 13976-13981.

[20] Dronova, I., Gong, P. and Wang, L. (2011), “Object-based analysis and change detection of major wetland cover types and their classification uncertainty during the low water period at Poyang Lake", China Remote Sens. Environ., 115, 3220-3236.

[21] Kaliraj, S., Meenakshi, S.M. and Malar, V.K. (2012), "Application of remote sensing in detection of forest cover changes using geo-statistical change detection matrices - A case study of Devanampatti Reserve Forest, Tamilnadu, India”, Nat. Environ. Pollut. Technol., 11, 261-269.

[22] Demir, B., Bovolo, F. and Bruzzone, L. (2013), "Updating land-cover maps by classification of image time series: A novel change-detection-driven transfer learning approach”, IEEE Trans. Geosci. Remote Sens., 51, 300-312.

[23] Brisco, B., Schmitt, A., Murnaghan, K., Kaya, S. and Roth, A. (2013) "Sar polarimetric change detection for flooded vegetation", Int. J. Digi. Earth, 6, 103114.

[24] Pal, S., Chattopadhyay, B. and Mukhopadhyay, S.K. (2016), "Spatio-temporal study of carbon sequestration through piscicultural practice at East Kolkata Wetland (A Ramsar Site), India”, J. Environ. Biol., 37(5), 965-971.

[25] Pal, S., Manna, S., Aich, A., Chattopadhyay, B. and Mukhopadhyay, S.K. (2014), "Assessment of the Spatio-Temporal Distribution of Soil Properties in East Kolkata Wetland Ecosystem (A Ramsar Site: 1208)" J. Earth Syst. Sci, 123(4), 729-740.

[26] Zhou, W. and Wu, B. (2008), "Assessment of soil erosion and sediment delivery ratio using remote sensing and GIS: A case study of upstream chaobaihe river catchment, North China", Int. J. Sediment Res., 23, 167-173.

[27] Sun, F., Sun, W., Chen, J. and Gong, P. (2012), "Comparison and improvement of methods for identifying waterbodies in remotely sensed imagery", Int. J. Remote Sens., 33, 6854-6875.

[28] Shekede, M., Kusangaya, S. and Schmidt, K. (2008), "Spatio-temporal variations of aquatic weed abundance and coverage in Lake Chivero, Zimbabwe", Phys. Chem. Earth, Parts A/B/C, 33, 714-721.

[29] Dube, T., Gumindoga, W. and Chawira, M. (2014), "Detection of land cover changes around Lake Mutirikwi, Zimbabwe, based on traditional remote sensing image classification techniques", Af. J. Aquat. Sci., 39(1), 89-95.

[30] Penatti, N.C., Almeida, T.I.R.., Ferreira, L.G., Arantes, A.E. and Coe, M.T. (2015), "Satellite based hydrological dynamics of the world's largest continuous wetland", Remote Sens. Environ., 170, 1-13.

[31] Gibbons, D.W. and Gregory, R.D. (2006), "Birds". In Ecological Census Techniques: A Handbook. (Ed. Sutherland, W.J.). Cambridge University Press, pp. 227-259.

[32] Bibby, C.J., Burgess, N.D. and Hill, D.A. (1992), "Bird census techniques", Academic Press, London.

[33] Gopal, B. (1995), "WWF Handbook of Wetland Management", World Wildlife Fund publication, New Delhi. pp. 1-395.

[34] Chatterjee, A., Adhikari, S., Barik, A. and Mukhopadhyay, S.K. (2013), "The mid-winter assemblage and diversity of bird populations at Patlakhawa Protected Forest, Coochbehar, West Bengal, India", The Ring, 35, 31-53. 
[35] Chatterjee, A., Adhikari, S. and Mukhopadhyay, S.K. (2017), "Effects of waterbird colonization on limnochemical features of a natural wetland on Buxa Tiger Reserve, India, during wintering period". Wetlands, 37(1), 177-190.

[36] Mukherjee, A., Pal, S. and Mukhopadhyay, S.K. (2020), "Diurnal time-activity budget and foraging techniques of red-crested pochards (Netta rufina) wintering at the wetlands of West Bengal, India", Turk. J. Zool., 44(5), 424-439.

[37] Chatterjee A., Adhikari S., Pal S. and Mukhopadhyay S.K. (2020), "Foraging guild structure and niche characteristics of waterbirds wintering in selected sub-Himalayan wetlands of India”, Ecol. Indic., 108. DOI: 10.1016/j.ecolind.2019.105693. 